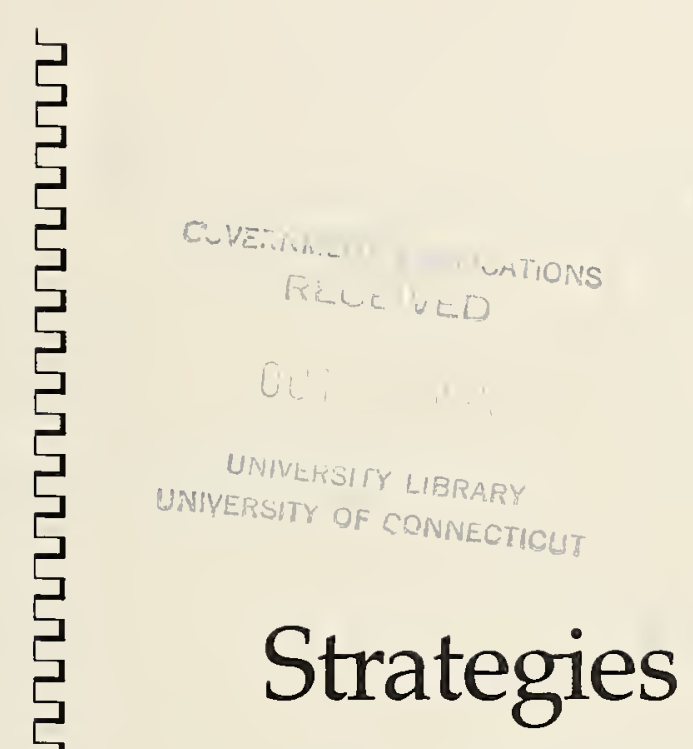

Experiment

for Reducing

Station,

Wildlife Damage

New Haven

in Orchards

BY ROBERT K. SWIHART

AND MICHAEL R. CONOVER

Bulletin 855

February 1988 
Digitized by the Internet Archive in 2011 with funding from

LYRASIS members and Sloan Foundation 


\title{
Strategies for Reducing
}

\section{Wildlife Damage in Orchards}

\author{
BY ROBERT K. SWIHART \\ AND MICHAEL R. CONOVER
}

Wildlife damage to crops is a major problem for orchardists in Connecticut. Four species cause the majority of damage and tree mortality occurring in Connecticut apple orchards: meadow voles (Microtus pennsylvanicus), pine voles

(Microtus pinetorum), white-triled deer

(Odocoileus virginianus), and woodchucks

(Marmota monax). Voles damage trees by gnawing the roots and main stem. Deer browse heavily on apple trees, especially dormant twigs and buds during winter. Woodchucks damage trees by gnawing and clawing them, and they dig burrows in orchards, thereby posing a hazard for both men and machinery. Here, we present information on the ecology and behavior of voles, deer, and woodchucks that relates to the control of damage caused by these species. We discuss field-tested techniques that orchardists can use to protect their plants as well as new methods which show promise.

\section{VOLES}

Voles as agricultural pests Two species of vole, meadow vole and pine vole, have posed problems in Connecticut orchards for at least 50 years (Merrill, 1939). These rodents damage fruit trees, primarily apple trees, from late fall through early spring by gnawing phloem and cambium tissues on the main stem and large lateral roots. Vole damage can result in reduced vigor, lower yields, and higher mortality of apple trees (Sullivan et al., 1980; Richmond et al., 1988). Damage by voles can be extensive, and control is costly. A survey of American orchardists in 1978 concluded that 123,000 apple trees were killed annually by voles, $37 \%$ of which were of fruit-bearing age (Ferguson, 1980). In Pennsylvania during the mid-1970s, growers spent four times more on control of voles than on deer and birds combined (Anthony and Fisher, 1977).

Damage by meadow voles is characterized by girdling and patches of gnaw marks on the stem close to the ground. Gnaw marks of voles differ from those of other gnawing animals (e.g., rabbits) because they are irregular in appearance, occurring at various angles on the stem. Individual tooth marks are only about $1 / 16$ inch wide. Damage by pine voles usually is not visible because it occurs underground.

The success of any control technique will be determined in part by the ecology and behavior of the pest species. For example, toxicantcoated grains often are not consumed by voles, probably because voles are not particularly fond of seeds; rather, they are almost entirely herbivorous (Batzli, 1985). Although meadow voles and pine voles both feed on apple trees, differences exist between the species. Understanding some of the major differences in their ecology and life history helps explain how control techniques might affect both species differently.

Behavior and ecology Meadow voles are distinguished from pine voles by their larger size, longer tail, and lighter fur (Figure 1). Adult meadow voles attain weights of 1.2 to $1.6 \mathrm{oz}$. The species is prolific even by rodent standards, with females capable of breeding at 26 days of age, having a gestation period of only 21 days, and litters most frequently numbering 5-6 young (Bee et al., 1981; Keller, 1985). Pine voles, in contrast, are considerably smaller, weighing only 0.6 to $0.9 \mathrm{oz}$. as adults (Miller and Getz, 1969). One consequence of their smaller size is that an adult pine vole could be expected to consume only about $70 \%$ of the daily food intake of an adult meadow vole. In addition, pine voles exhibit a lower potential 
for population growth; reproductive maturity of females is not attained until 33 days of age, and maturity may occur much later. Gestation periods (24 days) and litter sizes (2-3) of pine voles also indicate a reduced reproductive potential relative to meadow voles (Schadler and Butterstein, 1979).

Meadow voles travel in orchards through surface runways, which are built by clipping vegetation at ground level. These runways are most visible in early spring after snowmelt but prior to the growth of new vegetation. Pine voles do not use surface runways; they construct extensive tunnel systems below the soil surface, usually within the boundary marked by a tree's dripline. As a result, damage by pine voles generally is confined to roots, whereas meadow voles damage the main stem. Individual voles typically occupy a "home" area within the orchard, and although considerable variation exists regarding the size of home ranges, 0.05 acres is representative for meadow voles (Swihart et al., 1988). Home ranges of pine voles are only about one-fifth as large, averaging 0.01 acres (FitzGerald and Madison, 1983). Although both species will make use of areas under fruit trees, meadow voles also occupy the grassy areas between rows, especially when pine voles are present in the orchard
(Cranford and Derting, 1982). Pine voles may inhabit deciduous woods, but their numbers in such areas are low relative to populations in orchards (Miller and Getz, 1969). Meadow voles, on the other hand, do not inhabit wooded areas but are abundant in a number of agricultural habitats as well as in wet grasslands and roadsides (Getz, 1985). Because of their more wide-ranging movements and more general habitat requirements, meadow voles are more likely to infest or quickly recolonize on area. In addition to differences in habitat use, these two species exhibit different ways of foraging. Pine voles store food in their subterranean tunnels (Byers et al., 1976). Meadow voles do not typically store food; instead, they practice more of an "eat-as-you-go" strategy.

Sociality is more strongly developed in pine voles than in meadow voles. Pine voles live in extended family units of two to nine animals, typically consisting of two adult males, one adult female, and one to two juveniles and subadults (FitzGerald and Madison, 1983). Pine voles appear to be monogamous, and recent evidence suggests that only the dominant adult female breeds in a family unit; reproductive maturity of subadult females may be delayed by as much as 83 days because of volatile chemical
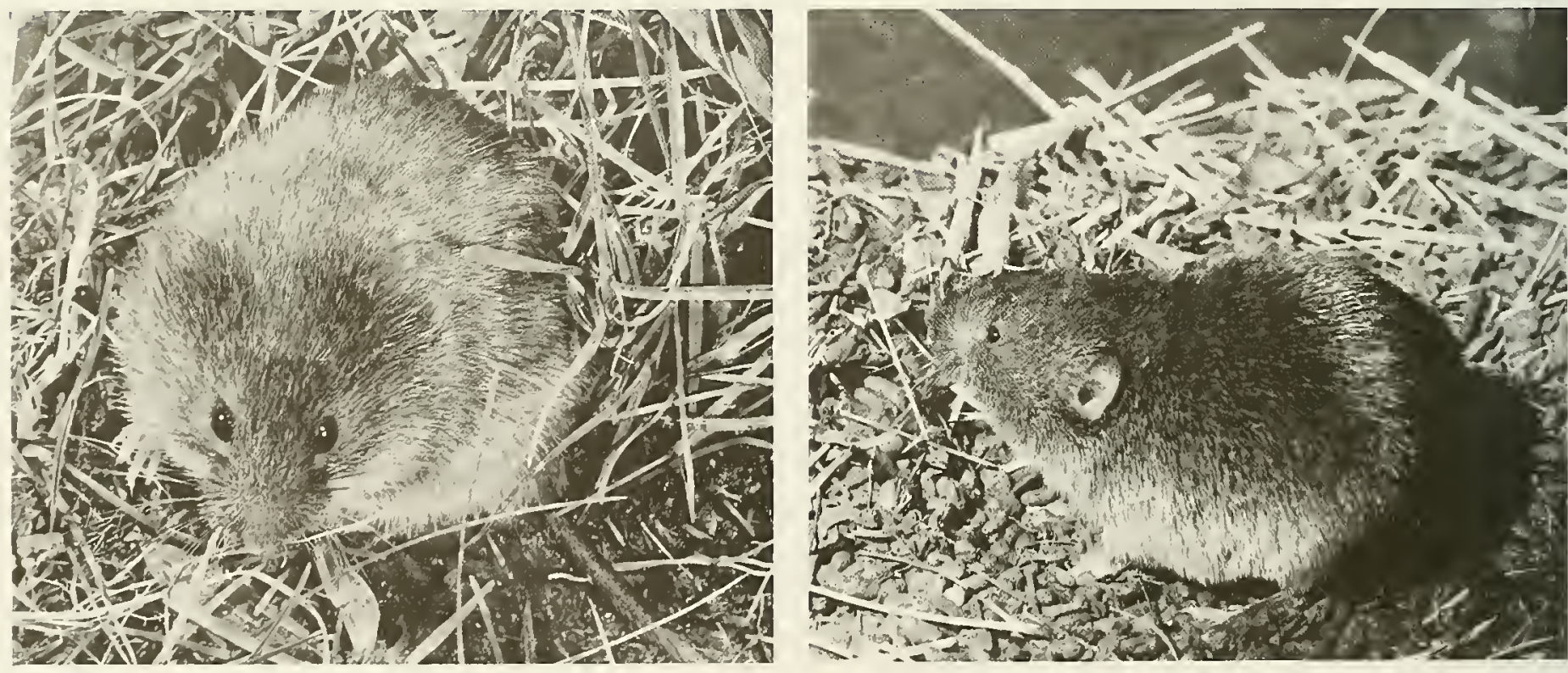

FIGURE 1-Meadow vole, left. Photo by Maslowski. Pine vole, right. Photo by R. Patterson. 
cues (pheromones) released by other family members (Anonymous, 1985). The social system of meadow voles is organized more loosely. Meadow voles are promiscuous, and females are territorial during the breeding season (Madison, 1980; Boonstra and Rodd, 1983). Extended family groups do not occur except perhaps on a limited seasonal basis.

\section{Population reduction The most effective} and widely practiced method of controlling vole damage relies on the use of toxic baits. Zinc phosphide (ZP) is the least expensive and most commonly used vole toxicant in Connecticut. $\mathrm{ZP}$ is available in pellets or in grain bait formulations and typically is hand-placed in the runways or burrows of voles at a rate of 1-5 lbs/acre. To attract voles, prevent ingestion by nontarget animals, and minimize exposure to the elements, baits often are placed under a protective cover (e.g., shingle, split tire). $Z P$ may also be broadcast in orchards at a rate of 10-15 lbs/acre. $\mathrm{ZP}$ is a single-dose toxicant capable of killing voles after one feeding. Reductions in vole activity of $85-94 \%$ have been associated with the use of ZP pellets; these reductions were found primarily in studies involving pine voles (Byers and Merson, 1982a,b; Merson and Byers, 1985).

One problem with $\mathrm{ZP}$ is that ingestion of $\mathrm{a}$ sublethal dose results in subsequent aversion to the compound. Consequently, multiple-dose toxicants that do not create a learned aversion are sometimes used. Two such toxicants are the anticoagulants chlorophacinone (Rozol) and diphacinone (Ramik). Broadcast treatment of chlorophacinone at $17-22 \mathrm{lbs} / \mathrm{acre}$ resulted in a reduction in pine vole activity of $86-99 \%$, and similar treatments with diphacinone produced 62-81\% control (Byers and Merson, 1982a; Merson and Byers, 1985).

Because of their behavioral and ecological differences, pine and meadow voles are affected differently by toxic baits. Anticoagulant baits are more effective against pine voles because their habit of storing food promotes repeated feeding on the bait by members of a family group (Byers, 1984). In addition, hand placement of toxic baits might be expected to control pine voles better than meadow voles because the majority of baiting is done within the dripline of a row, whereas meadow voles are often found outside this area and in adjoining habitats.

Snap trapping provides another means of reducing vole populations. However, trapping is probably impractical in large orchards because many traps are required, the time necessary to set and check traps is great, and "trap-shy" individuals will not be captured.

Exclusion Tree guards may be useful in reducing damage by meadow voles to young trees, and expandable coil tree guards that are wrapped around the main stem reduce maintenance costs. These wraparound tree guards generally are not effective against pine voles, though, because of their burrowing habits (Caslick and Decker, 1978). Hardware cloth cylinders ( $1 / 4$ inch mesh) buried to a depth of 6 inches have been suggested for exclusion of pine and meadow voles from young trees (O'Brien, 1983). If hardware cloth guards are used, they should be fitted with 4-6 inch wide aluminum flashing along the upper edge, because our observations indicate that meadow voles can easily climb hardware cloth. Also, the cylinders should be spaced far enough from the tree to permit trunk growth.

Cultural practices Cultural methods have also reduced damage by voles. Minimizing the amount of litter and vegetative cover under trees reduces the desirability of the site to voles. For instance, treatment of a 6-foot strip centered on a tree row with the herbicides simazine and glyphosate (4 and $1 \mathrm{lbs} / \mathrm{acre}$ ) in May followed with glyphosate in July $(0.5 \%$, spot spray) reduced pine vole damage to Connecticut apple trees by nearly $50 \%$ relative to unmowed areas (Moore and Ahrens, unpubl. data). Control of vegetation bordering orchards is also an important consideration (Cummins et al, 1984), especially when meadow voles are a problem.

Management of ground cover for vole control has received some attention, but rigorous testing has yet to be conducted. Traditionally, ground covers in orchards are chosen for how well they tolerate heavy equipment, conserve soil, and retain nutrients and water. But ground cover also serves as the food base for vole populations, so ground covers should be chosen with this in mind. One approach is to identify plants that are unpalatable to voles and assess their suitability as ground covers. For instance, crown vetch (Coronilla varia), a legume, is 
unpalatable to voles and typically harbors low densities of voles in natural settings (Jones 1978; Lewis et al. 1983; and Byers 1984). In addition to being unpalatable to voles, an established field of crown vetch would not be invaded by dandelions or other low-growing perennial forbs (R. Peters, pers. commun.). However, crown vetch is difficult to establish because of its slow growth. Planting it in combination with grass will aid in its establishment and prevent invasion of other weeds. Once established, crown vetch will outcompete grasses and should be able to tolerate mowing two to three times per growing season, but its ability to withstand consistent traffic is unknown (N. Hartwig, pers. commun.).

Horsfall et al. (1974), noting that voles prefer forbs (e.g., clover, alfalfa) over grasses, suggested that a reduction in damage to trees would occur if the availability of alternative foods such as broad-leaved forbs were increased. Although short-term reductions in damage might occur, it is likely that the increased survival and reproduction of voles resulting from an increased food supply could lead to serious damage after 1-2 years of population growth, particularly with the prolific meadow vole. A more beneficial strategy, particularly in young orchards without vole infestations, might be to devise an herbicide program to encourage a grass monoculture. For example, fall application of 2,4-D reduces forbs and enhances turf growth (J. Ahrens, pers, commun.). Fewer forbs could aid control by reducing either the maximum number of voles that the site could support, the rate at which vole populations grow, or both.

Repellents We are testing compounds in the laboratory for their ability to repel meadow voles from apple stems. Thus far we have examined three compounds: thiram, methiocarb, and quebracho (a condensed tannin produced by some plants). All exhibit significant degrees of repellency. In preliminary studies, thiram reduced damage by nearly $80 \%$ relative to untreated controls. Methiocarb, which has been used as a repellent of other wildlife species (Conover 1982, 1985), reduced damage by about $68 \%$. In Illinois, prairie voles, Microtus ochrogaster, lost weight and averted from food containing quebracho (Lindroth and Batzli, 1984). In our experiments with meadow voles, two mixtures of quebracho ( $1 \%$ and $3 \%$ of total dry weight) reduced damage to stems by about $33 \%$ and $68 \%$, respectively.

Resistant trees Laboratory tests indicate that voles prefer some varieties of apple trees over others (Byers and Cummins, 1977;

Wysolmerski et al., 1980). A hybrid of Malus prunifolia and $M$. sieboldii exhibits resistance to damage by both pine and meadow voles, primarily due to its taste and texture (Geyer and Cummins, 1980). Resistance is transmitted to an estimated $70 \%$ of the progeny (J. Cummins, pers. commun.). The hybrid's resistance to voles is not complete, though, for Cummins et al. (1984) indicated that meadow voles under hunger stress damaged it. The rootstock, termed "Novole" and introduced by the New York State Agricultural Experiment Station as PI 286613, also is resistant to crown rot, Phytophthora cactorum, and fire blight, Erwinia amylovora (Cummins et al., 1983). It produces vigorous standard trees, and hence should be used as a trunk and root system with a highworked interstem of a dwarfing clone. PI286613 is patented but is not yet sold commercially. No data exists on fruit production or quality.

Current work Common to virtually all the control techniques discussed above is that their effectiveness depends to varying degrees on vole population sizes and food availability. For instance, if vole numbers are low and alternative foods are plentiful, a control technique may appear to work well simply because conditions mitigated against a severe problem. We are conducting field experiments to enable us to predict the effectiveness of a repellent as a function of meadow vole density and the availability of alternative food. These experiments should allow us to predict the levei of protection afforded trees under a variety of conditions, thereby enabling orchardists and landowners to make better-informed decisions when designing a strategy for vole control.

\section{W HITE-TAILED DEER}

Deer as agricultural pests In the early $1980 \mathrm{~s}$, Connecticut harbored an estimated 25,000 deer (Ellingwood and Spignesi, 1987). With this growing population has come increasing problems for apple growers and nurserymen because of 
deer browsing. During the growing season, deer consume some apple leaves, shoots, and ripening fruit, but the damage usually is not extensive enough to injure the plant. During the winter, however, when food supplies are most limited, damage to apple trees can become severe. Katsma and Rusch (1980) found that removal of $40 \%$ of the buds on apple trees during the winter led to a significant reduction in fruit production the following year. Most vulnerable are young apple trees. Deer browsing on the leader branches may cause young trees to become misshapen or stunted, thus lowering their future fruit production (Harder, 1970).

Deer damage apple trees primarily by browsing the terminal shoots of dormant twigs. Browsed shoots 3-6 feet above the ground or snow line are an indication of deer damage. Deer browsing can be distinguished from rabbit browsing by the ragged and torn appearance of the ends of twigs. Twigs browsed by rabbits are cut cleanly at an angle close to $45^{\circ}$. The presence of deer can also be determined by checking for tracks and oval-shaped fecal pellets. Rabbits have more spherical, pill-shaped pellets.

Behavior and ecology Deer feed on a variety of vegetation. In the summer, they consume grass, forbs, and the leaves of many

\section{SPINDLE TREE}

JAPANESE YEW

ARBORVITAE

JAPANESE HOLLY

RED CEDAR

MOUNTAIN LAUREL

GOLDEN-BELLS

AMERICAN HOLLY

NORWAY SPRUCE

PEAR

FIGURE 2--Percent of shoots browsed by deer on different plant species at the same location. trees and shrubs. They also feed on farm crops such as pumpkins, corn, and alfalfa. During the winter when food supplies are low, deer survive by utilizing fat reserves and by browsing on buds and woody stems. Deer, however, do not feed randomly; some plants such as yews and apple trees are highly palatable, whereas other plants such as scotch pine and pear are rarely eaten by deer (Figure 2; Conover and Kania, 1988). Yet deer will browse small amounts of almost any plant species. This is probably advantageous as deer can consume small amounts of many toxic plants without ill effects and a varied diet helps insure that a deer will ingest essential minerals and vitamins (Westoby, 1978).

White-tailed deer are normally sedentary, restricting their activities to a home range of less than a mile in diameter (Marchinton and Hirth, 1984). Yet in any given year, some deer, primarily young males, disperse by leaving their home range to seek a new one. In one study in Mlinois, less than $10 \%$ of the adult deer dispersed yearly, but $80 \%$ of the 1-year-old bucks did so (Hawkins et al., 1971). Even for deer that remain within their home range, however, there are often seasonal shifts in the activity center. These shifts usually occur as deer move to take advantage of available food supplies (Marchinton and Hirth, 1984). Both dispersal and seasonal shifts in home range are important in determining levels of damage in an orchard. High rates of dispersal bring more deer in contact with orchard trees, but for relatively short periods of time. When deer adjust their home ranges seasonally to include an orchard, a longer tenure time is likely for each individual. Thus, the relative contributions of transients and residents to damage in an orchard may be important in determining the effectiveness of control methods such as repellents or population reduction.

Males grow and shed antlers yearly. After antler growth stops in late summer or early fall bucks rub their antlers against trees, especially saplings, to remove the protective covering known as velvet. Bucks often rub trees hard enough to remove the bark, break branches, or knock the tree over. However, in the apple orchards we examined in Connecticut, only a few trees were lost this way yearly (Conover and Kania, 1988). 
Population reduction Farmers who are suffering from deer damage to their crops can apply for crop damage deer permits, which allow them or their agents to shoot deer on their property from one half hour before sunrise to one half hour after sunset throughout the year. To obtain a permit, the farmer has to (1) earn or have the potential to gross $\$ 500$ per year from his crops and (2) suffer confirmable deer damage. Once an application is filed, the farm will be inspected by the Department of

Environmental Protection for deer damage and to insure that the site can be safely hunted. If daytime hunting is ineffective because deer are entering the property only after dark, farmers can seek special permits to hunt at night.

Exclusion In many cases, erecting a deerproof fence may be the only available method to stop deer from damaging a crop. The main problem with fencing is the cost of construction, but the cost can be amortized (Caslick and Decker, 1977, 1979). There is much variation in types of fences and their cost and effectiveness. Temporary electric fences can be used to discourage deer from entering a field (Porter, 1983). These fences work by altering a deer's behavior rather than by physically preventing it from crossing. They are most effective when farmers can anticipate a problem with deer and turn the electricity on before damage begins. These fences are inexpensive; cost, excluding labor, is about $\$ 0.10$ per foot (Craven and Hygnstrom, 1987). With an electric fence, it is probably worthwhile to pay extra for a powerful electric charger, because the fence has to provide enough of a jolt to discourage the deer from trying to go through the fence again.

Permanent electric fences are usually made of high-tensile fencing; cost, excluding labor, ranges from \$0.50-\$1.50 per foot (Palmer et al., 1985; Craven and Hygnstrom, 1987). Two types are commonly used. One is a vertical six-wire fence with the bottom wire 8 inches above the ground and the other wires spaced one foot apart. The other type is a slant design where the fence is installed at a $45^{\circ}$ angle facing outward. Both designs have worked well in excluding deer (Palmer et al., 1985; Ellingwood et al., 1985).

Permanent woven wire fences are very effective in keeping deer out of fields but are difficult to construct and cost $\$ 2-4.00$ per foot, excluding labor (Craven and Hygnstrom, 1987).

Cultural practices When establishing a new orchard, farmers should consider whether deer are likely to pose a major problem. To examine whether deer damage is likely to occur at any particular site, we compared extent of damage to yews in nurseries to several characteristics of the nursery itself. For each nursery examined, we recorded: (1) its size and proximity to houses and roads; (2) the size of woodlots both adjoining and not adjoining but less than $2 \mathrm{~km}$ from the nursery; (3) the size and density of the local deer population; and (4) the amount of alternate food available to deer. We found that, of these characteristics, deer damage was best correlated with the number of deer in the adjoining woodlots. Hence, farmers can assess the potential for deer damage at a site, even before it is planted, by estimating the number of deer in adjacent woodlots. The latter is relatively easy to measure by counting the number of deer pellet groups in several randomly-selected plots in the adjacent woodlots. A formula can then be used to convert this data to deer numbers (Neff, 1968). If damage is likely at a site, some preventative steps can be taken to reduce the potential problem. For instance, it may be worthwhile to erect a deer-proof fence at the outset.

More damage will occur in a small orchard than in a large one because a larger percentage of trees will be close to the edges of woods. Hence, deer damage may be less if all apple trees are located in one large field rather than scattered in several small fields. Deer damage will be reduced if apple orchards are placed away from woodlots. Dwarf and semidwarf trees are more vulnerable to damage than standard trees because more of their foliage is within reach of deer. Peaches, pears, and blueberries, which are less palatable to deer than apples, may be better crops in isolated fields where damage is expected.

Planting of diversionary crops has been suggested as a means of reducing deer damage. The idea is that deer will feed on diversionary crops and leave apple trees alone. Two problems limit the usefulness of this method. First, the deer population will increase because 
more will survive the winter and their breeding success will increase because they will be in better condition. In one study, when supplemental food was provided for 5 years to deer in a 622-acre enclosure, the herd increased from 23 to 159 (Ozoga and Verme, 1982).

The second problem is that by providing a palatable food for deer, especially during winter, a farmer may attract a higher percentage of the local deer to his orchard (Matschke et al,, 1984). This problem is compounded by the fact that deer often browse on available plants as they pass by them. Hence, while deer may fill most of their nutritional needs on the diversionary crop, they may still browse on the apple trees. This suggests that a diversionary crop may be most useful if planted away from the apple orchard but within the home range of the deer browsing in the apple orchard. The winter of 1986-1987, we conducted a preliminary experiment to try to divert deer from nursery plants by providing diversionary food approximately 200 yards away when several inches of snow covered the ground. The .ttempt apparently failed, however, as deer damage to the nursery plants was similar to what it had been the year before. Changes in the number of deer or their movements could have influenced our results; thus, this experiment is being continued over the next few years.

One problem we face is that we do not know the optimal distance to locate a diversionary crop from a nursery or orchard. Therefore, we are examining the home range of deer by placing radio transmitters on animals caught in and adjacent to nurseries. By tracking their movements during the course of a year, we will collect information on the size of areas used by individuals, seasonal shifts in areas used, and the timing of use of agricultural areas. By assessing movements of deer in and around nurseries, this study may also prove useful in determining how successful removal programs are.

Repellents Several chemicals are sold as deer repellents, and home-made remedies abound. Unfortunately, little information is available about their effectiveness. We tested six repellents in commercial nurseries in Connecticut to determine if they could reduce deer damage to Japanese yews, Taxus cuspidata, (Conover,
1984, 1987). In this experiment, 0.025 acre plots were established within large fields of yews. Some plots were treated with one of the repellents while others were left untreated as a control. The amount of deer browsing in these plots was monitored throughout the winter. By winter's end, deer browsing was $15 \%$ to $46 \%$ lower in the treated plots than in the untreated control plots (Figure 3). We further tested the two most effective repellents, BGR and Hinder, by spraying 0.5 acre plots of yews with them (Conover, 1987). In this test, deer browsing was reduced by about $50 \%$ by winter's end in both $\mathrm{BGR}$ and Hinder plots compared to the untreated control plots.

We also tested the effectiveness of BGR, human hair, and a mixture of blood meal and peppercorns in reducing deer damage to young apple trees. In one orchard, deer browsed an average of 1.1 buds per untreated tree, 0.8 on trees treated with $\mathrm{BGR}$, and 0.5 on trees treated with human hair. In another orchard, deer browsed an average of 2.9 buds on untreated trees, 1.1 on trees with bags containing human hair and 1.2 on trees with bags containing blood meal and peppercorns. Thus, in all of these tests repellents reduced damage by

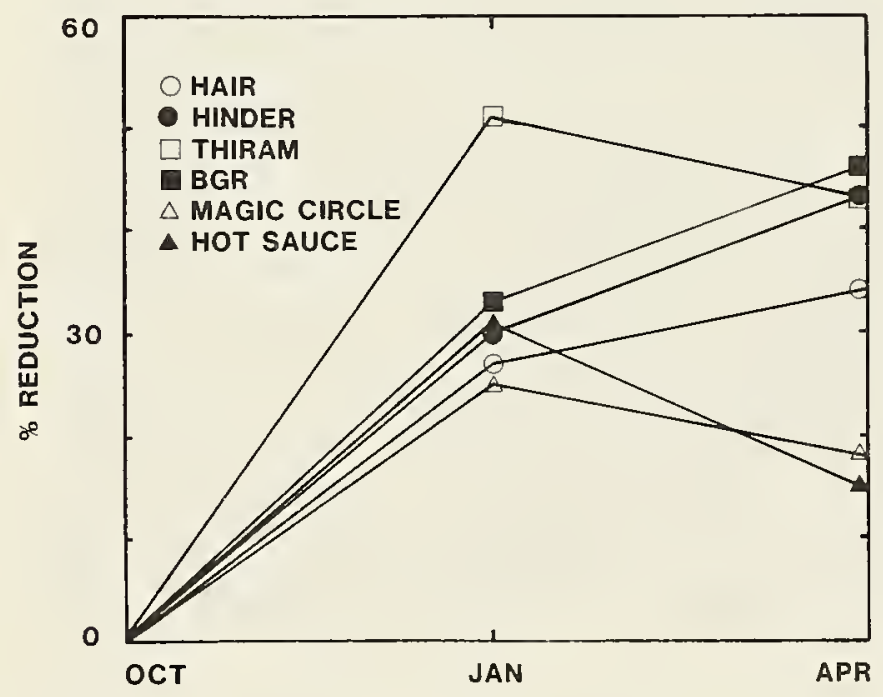

FIGURE 3-Percent reduction in browsing in plots of yews treated once in the fall with a repellent when compared to nearby plots left untreated. 
25-50\%, but no repellent eliminated damage entirely.

Cost is an important consideration in selecting a repellent. Materials to make bags containing human hair or blood meal and peppercorns are inexpensive but considerable labor is required to make the bags and tie them to the trees. In contrast, some spray repellents, such as BGR, are costly to purchase but require less labor to use.

\section{WOODCHUCKS}

Woodchucks as agricultural pests The woodchuck is a ground-dwelling member of the squirrel family which commonly inhabits orchards in Connecticut. Three of their activities may present problems for orchardists: burrows and associated mounds of excavated soil can be hazardous to machinery; burrows at the base of trees may cause excessive aeration of roots and upheaval of the tree; and gnawing and clawing of fruit trees can severely damage or even kill young trees. Gnawing damage usually occurs on the main stem of trees located close to burrows and can be distinguished from vole gnawing by the larger size of the incisor marks $(1 / 8$ to $3 / 8$ inch wide). Woodchucks also climb trees

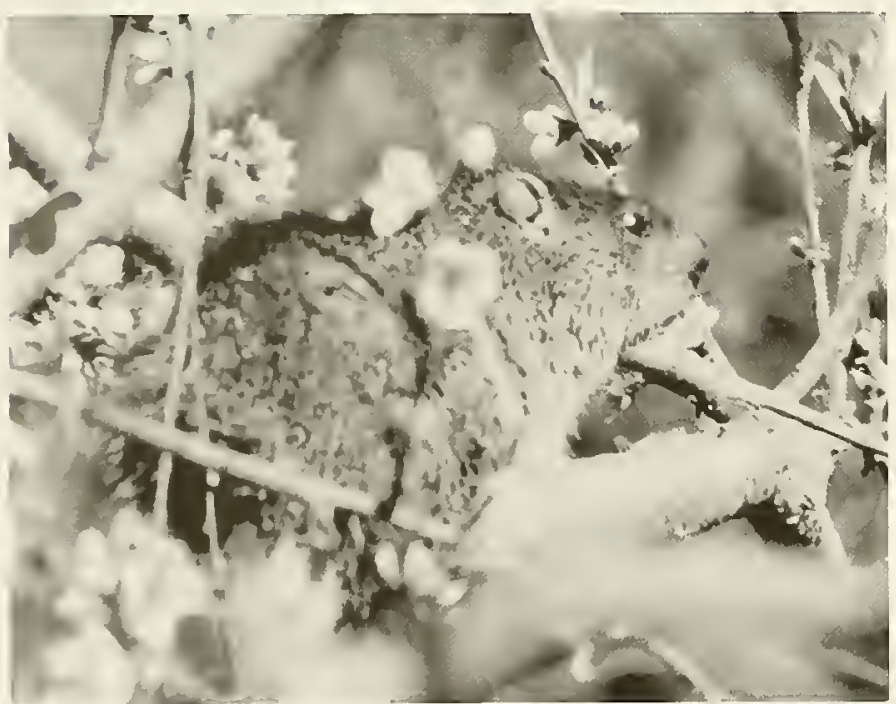

FIGURE 4-Although primarily found on or under the ground, woodchucks will climb trees, often using them as sunning posts. This woodchuck is eight feet above the ground in a peach tree. Photo by $\mathrm{P}$. Picone.
(Figure 4; Swihart, 1982) and damage lower branches. Clawing of trees results in shredded bark 1 to 3 feet above the ground.

Behavior and ecology Woodchucks are true hibernators, usually becoming inactive in November and emerging from burrows in March. Hence, unlike voles and deer, woodchucks do not cause damage during the winter. Breeding occurs in early spring, and an average of four young are born after a 32-day gestation period. Woodchucks are primarily active around dawn and dusk, with little above ground movement occurring from 10:30 p.m. to 6:00 a.m. (Merriam, 1963).

Population reduction Orchardists typically rely on lethal control techniques. Poisonous gas introduced into sealed burrows is one method used (Byers, 1984). By monitoring burrows treated by a landowner, we found that 10 of 35 burrows (28\%) had been reoccupied within 2 days, $83 \%$ within 2 weeks, and $86 \%$ within 1 month of treatment. Part of the reason for the shortterm effectiveness of the treatment in this case may have been due to its timing. Treatment of burrows occurred during the day when woodchucks were least likely to occupy their burrows. Although we have no data on the proportion of burrows occupied by residents which survived the treatment, it is likely that survivors reopened the burrows on the same day. In addition, our findings indicate that several woodchucks may use a single burrow, albeit usually not at the same time. This also would contribute to a rapid reoccupation of empty burrows.

The removal of woodchucks by shooting or trapping also has not been demonstrated to be effective in protecting an orchard. During a 4-year population study in Pennsylvania, a total of 1040 woodchucks were removed from a $600-$ acre site by shooting or trapping (Davis et al., 1964). Nonetheless, the population size at this site was unaffected, primarily because of increased juvenile survival, higher birth rates, and substantial immigration (Davis et al., 1964).

Exclusion Woodchucks may be excluded from small areas by combining a 4-foot high hardware cloth fence buried 10-12 inches with an electric hot-shot wire 4-5 inches high outside the fence (Bollengier, 1983). Exclusion usually is not practical for commercial growers. 
Current work We have initiated a field study of woodchucks with the intent of learning more about their social system, behavior, and ecology. By mapping burrow systems, monitoring the movements of radio-collared individuals, livetrapping animals, and measuring various features of the habitat around burrows, we are examining aspects of woodchuck movements, habitat use, burrow placement, and population ecology that should prove useful in devising effective controls.

We are investigating two ways of reducing damage caused by woodchuck gnawing and clawing. First, we are examining ways of increasing the amount of time before an empty burrow is recolonized by a woodchuck. Wild canids such as foxes and coyotes are natural predators of woodchucks which also modify woodchuck burrows into dens for their own use (Grizzell, 1955; Parker, 1986). We are testing predator odors for their ability to repel woodchucks from a burrow by spraying the entrance area with fox or coyote urine and noting how long it takes for recolonization to occur relative to untreated control burrows. Odors of naturally-occurring predators have been used successfully to modify feeding behavior of snowshoe hares (Sullivan, 1986; Sullivan and Crump, 1984, 1986).

A second experiment involves the use of "gnawing" posts to protect young fruit trees. Woodchucks presumably gnaw trees to wear down their incisors and/or to communicate with other woodchucks by leaving their scent on the tree. By providing alternative sites adjacent to trees, it may be possible to shift most of the gnawing activity from the trees to the posts.

\section{SUM M ARY}

The most common method of controlling voles in orchards is use of the toxicants zinc phosphide, chlorophacinone, or diphacinone. Herbicide treatments to reduce growth of herbaceous plants in orchards also have been effective against voles. Deer damage can be reduced by installing fences, applying repellents, or using cultural techniques. Removing pest deer by hunting is another option. Woodchucks are controlled in a variety of ways aimed at population reduction. Unfortunately, these methods are not always effective.
When choosing a control strategy, an understanding of the behavior and ecology of the pest species is helpful. Past techniques which have ignored these facets of a species' biology often have failed. In addition, an understanding of the pest population as a dynamic, constantly changing group of individuals is important. For instance, dispersing animals may quickly settle into an area following a population decline. Because of this, removal techniques usually offer only short-term solutions. Modifying the animal's behavior and devising ecologically sound control measures offer considerable promise for longer-term solutions to pest problems in orchards.

\section{LITERATURE CITED}

Anonymous. 1985. Coming of age. Research Perspectives, North Carolina Agric. Res. Serv., $4(3): 9$.

Anthony, R.G. and A.R. Fisher. 1977. Wildlife damage in orchards - a need for better management. Wildi. Soc. Bull. 5:107-112.

Batzli, G.O. 1985. Nutrition. Pages 779-811 in R.H. Tamarin (ed.) Biology of New World Microtus. Special Publ. No. 8, Amer. Soc. Mammal.

Bee, J.W., G.E. Glass, R.S. Hoffmann and R.R. Patterson. 1981. Mammals in Kansas. Publ. Educ. Series No. 7, Museum of Natural History, Univ. of Kansas, Lawrence. 300 pp.

Bollengier, R.M., Jr. 1983. Woodchucks. Pages $\mathrm{B}-153$ to $\mathrm{B}-156$ in R.M. Timm (ed.), Prevention and control of wildlife damage. Great Plains Agric. Council Wildl. Resour. Comm. and Coop. Ext. Serv, Inst. of Agric, and Nat. Resour., Univ. Nebraska, Lincoln.

Boonstra, R. and F.H. Rodd. 1983. Regulation of breeding density in Microtus pennsylvanicus. J. Anim. Ecol, 52:757-780.

Byers, R.E. 1984. Control and management of vertebrate pests in deciduous orchards of the eastern United States. Hort. Rev, 6:253-285.

Byers, R.E. and J.N. Cummins. 1977. Variations in susceptibility of apple stems to 
attack by pine voles. J. Amer. Soc. Hort. Sci. 102:201-203.

Byers, R.E. and M.H. Merson. 1982. Current improvements in baiting pine and meadow voles. Pages 139-142 in R.E. Marsh (ed.) Proc. 10th Vert. Pest Conf.

Byers, R.E., R.S. Young and R.D. Neely. 1976. Review of cultural and other control methods for reducing pine vole populations in apple orchards. Pages 242-253 in C.C. Siebe (ed.) Proc. 7th Vert. Pest Control Conf.

Caslick, J.W. and D.J. Decker. 1977. Benefitcost analysis of a deer-proof fence for apple orchards. Conserv. Circ. 15(4), Dept. Nat. Resour. N.Y.S. Coll. of Agric. \& Life Sci., Cornell Univ., Ithaca. 3 pp.

Caslick, J.W. and D.J. Decker. 1978. Control of wildlife damage in orchards and vineyards. Cornell Univ. Coop. Ext. Info. Bull. 146:1-18.

Caslick, J.W. and D.J. Decker. 1979. Economic feasibility of a deer-proof fence for apple orchards. Wildl. Soc. Bull. 7:173-175.

Conover, M.R. 1982. Behavioral techniques to reduce bird damage to blueberries: methiocarb and a hawk-kite predator model. Wildl. Soc. Bull, 10:211-216.

Conover, M.R. 1984. Effectiveness of repellents in reducing deer damage in nurseries. Wildl. Soc. Bull. 12:399-404.

Conover, M.R. 1985. Using conditioned food aversions to protect blueberries from birds: comparison of two carbamate repellents. Appl. Anim. Behav. Sci. 13:383-386.

Conover, M.R. 1987. Comparison of two repellents for reducing deer damage to Japanese yews during winter. Wildl. Soc. Bull. 15:265-268.

Conover, M.R. and G.S. Kania. 1987.

Effectiveness of human hair, BGR, and a mixture of blood meal and peppercorns in reducing deer damage to young apple trees. Proc. East. Wildl. Damage Control Conf. (In press).

Conover, M.R. and G.S. Kania 1988. Browsing preference of white-tailed deer for different ornamental species. Wildl. Soc. Bull. (In press).
Cranford, J.A. and T.L. Derting. 1983. Intra and interspecific behavior of Microtus pennsylvanicus and Microtus pinetorum. Behav. Ecol. Sociobiol. 13:7-11.

Craven, S. and S. Hygnstrom. 1987. Controlling deer damage in Wisconsin. Univ. Wisc., Coop. Ext. Serv. Bull. G3083, 12pp.

Cummins, J.N., H.S. Aldwinckle and R.E. Byers. 1984. 'Novole': a crabapple selected for resistance to pine voles and meadow voles. HortScience 19:162.

Cummins, J.N., H.S. Aldwinckle and R.E. Byers. 1983. 'Novole' apple. HortScience 18:772-774.

Davis, D.E., J.J. Christian and F. Bronson. 1964. Effect of exploitation on birth, mortality, and movement rates in a woodchuck population. J. Wildl. Manage. 28:1-9.

Ellingwood, M. and J. Spignesi. 1987. Connecticut deer program summary 1980-1984. Conn. Dept. Envir. Prot., Wildl. Bureau Publ. DR-7, 16pp.

Ellingwood, M.R., J.B. McAninch and M.J. Fargione. 1985. Current status of deer fencing in the Northeast. Pages $180-185$ in P.T. Bromley (ed.), Proc. 2nd East. Wildl. Control Conf.

Ferguson, W.L. 1980. Rodenticide use in apple orchards. Pages 2-8 in R.E. Byers (ed.), Proc. 4th Eastern Pine and Meadow Vole Symp.

FitzGerald, R.W. and D.M. Madison. 1983. Social organization of a free-ranging population of pine voles, Microtus pinetorum. Behav. Ecol. Sociobiol. 13:183-187.

Getz, L.L. 1985. Habitats. Pages 286-309 in R.H. Tamarin (ed.) Biology of New World Microtus. Special Publ. No. 8, Amer. Soc. Mammal.

Geyer, L.A. and J.N. Cummins, 1980. Textural and taste influences on gnawing by pine voles. Pages 43-49 in R.E. Byers (ed.), Proc. 4th Eastern Pine and Meadow Vole Symp.

Grizzell, R.A., Jr. 1955. A study of the southern woodchuck Marmota monax monax. Amer. Midland Natur. 53:257-293. 
Harder, J.D. 1970. Evaluating winter deer use of orchards in western Colorado. Trans. N. Am. Wildl. Conf. $35: 35-47$.

Hawkins, R.E., W.D. Klimstra, and D.C. Autry. 1971. Dispersal of deer from Crab Orchard National Wildlife Refuge. J. Wildl. Manage. $35: 216-220$.

Horsfall, F., Jr., R.E. Webb and R.E. Byers. 1974. Dual role of forbs and rodenticides in the ground spray control of pine voles. Pages 112-125 in Proc. 6th Vert. Pest Control Conf.

Jones, E.N. 1978. Influences of crownvetch (Coronilla varia L.) on the density and spatial distribution of the meadow vole (Microtus pennsylvanicus). Unpubl. M.S. Thesis, Pennsylvania State University. 52 pp.

Katsma, D.E. and D.H. Rusch 1980. Effects of simulated deer browsing on branches of apple trees, J. Wildl. Manage, 44:603-612.

Keller, B.L. 1985. Reproductive patterns. Pages 725-778 in R.H. Tamarin (ed.) Biology of New World Microtus. Special Publ. No. 8, Amer. Soc. Mammal.

Lewis, E., D.H. Rhodes and M. Richmond. 1983. Acceptability of six candidate groundcovers to meadow voles. Pages 87-92 in R.E. Byers (ed.) Proc. 7th Eastern Pine and Meadow Vole Symp.

Lindroth, R.L. and G.O. Batzli. 1984. Plant phenolics as chemical defenses: effects of natural phenolics on survival and growth of prairie voles (Microtus ochrogaster). J. Chem. Ecol. 10:229-244.

Madison, D.M. 1980. Space use and social structure in meadow voles, Microtus pennsylvanicus. Behav. Ecol. Sociobiol. 7:65-71.

Marchinton, R.L. and D.H. Hirth. 1984. Behavior. Pages 129-168 in L.K. Halls (ed.) White-tailed Deer Ecology and Management. Stackpole Books, Harrisburg, PA.

Matschke, G.H., D.S. deCalesta, and J.D. Harder. 1984. Crop damage and control. Pages 647-654 in L.K. Halls (ed.) White-tailed Deer Ecology and Management. Stackpole Books, Harrisburg, PA. Merriam, H.G. 1963. Low frequency telemetric monitoring of woodchuck movements. Pages
155-171 in L. Slater (ed.) Bio-telemetry.

Pergamon Press, New York.

Merrill, H.A. 1939. Rodent control. Conn. Agric. Exp. Stn. Bull. No. 434, pp. 254-258.

Merson, M.H. and R.E. Byers. 1985. Weathering and the field efficacy of pelletized rodenticide baits in orchards. Crop Protection 4:511-519.

Miller, D.H. and L.L. Getz. 1969. Life-history notes on Microtus pinetorum in central Connecticut. J. Mammal. 50:777-784.

Neff, D.J. 1968. The pellet-group count technique for big game trends, census, and distribution: a review. J. Wild. Manage. 32:597614.

O'Brien, J.M. 1983. Voles. Pages B-147 to B152 in R.M. Timm (ed.) Prevention and Control of Wildlife Damage. Great Plains Agric. Council Wildl. Resour. Comm, and Coop. Ext. Serv., Inst. of Agric. and Natur. Resour., Univ. Nebraska, Lincoln.

Ozoga, J.J. and L.J. Verme. 1982. Physical and reproductive characteristics of $a$

supplementally-fed white-tailed deer herd. J. Wildl. Manage. 46:281-301.

Palmer, W.L., J.M. Payne, R.G. Wingard, and J.L. George. 1985. A practical fence to reduce deer damage. Wildl. Soc. Bull. 13:240-245.

Parker, G.R. 1986. The seasonal diet of coyotes, Canis latrans, in northern New Brunswick. Canadian Field-Naturalist 100:74-77.

Porter, W.F. 1983. A baited electric fence for controlling deer damage to orchard seedlings. Wildl. Soc, Bull, 11:325-327.

Richmond, M.E., C.G. Forshey and P.N. Miller. 1988. An experimental analysis of effects of known pine vole populations on tree root girdling, tree vigor, and fruit production. Proc. 3rd Eastern Wildl. Damage Control Conf., in press.

Schadler, M.H. and G.M. Butterstein. 1979. Reproduction in the pine vole, Microtus pinetorum. J. Mammal. 60:841-844. 
Sullivan, T.P. 1986. Influence of wolverine (Gulo gulo) odor on feeding behavior of snowshoe hares (Lepus americanus). J. Mammal. 67:385388.

Sullivan, T.P. and D.R. Crump. 1986. Feeding responses of snowshoe hares (Lepus americanus) to volatile constituents of red fox (Vulpes vulpes) urine. J. Chem. Ecol. 12:729-739.

Sullivan, T.P. and D.R. Crump. 1984. Influences of mustelid scent-glend compounds on suppression of feeding by snowshoe hares (Lepus americanus). J. Chem. Ecol. 10:1809-1821.

Sullivan, W.T., Jr., T.B. Sutton and D.W. Hayne. 1980. Apple tree mortality, rate and causes. Pages 62-65 in R.E. Byers (ed.) Proc. 4th Eastern Pine and Meadow Vole Symp.
Swihart, R.K. 1982. Scansorial behavior in woodchucks, Marmota monax. Canadian FieldNat. 96:215-216.

Swihart, R.K., N.A. Slade, and B.J. Bergstrom. 1988. Relating body size to the rate of homerange use in mammals. Ecology, in press.

Westoby, M. 1978. What are the biological bases of varied diets? Amer. Nat, 112:627-631.

Wysolmerski, J.C., R.E. Byers and J.N. Cummins. 1980. Laboratory evaluation of some Malus clones for susceptibility to girdling by pine voles, J. Amer. Soc. Hort. Sci. 105:675-677. 


